\title{
A potential role for the cerebellar nuclei in absence seizures
}

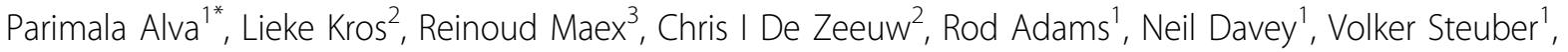 \\ Freek E Hoebeek ${ }^{2}$ \\ From Twenty Second Annual Computational Neuroscience Meeting: CNS*2013 \\ Paris, France. 13-18 July 2013
}

Absence seizures are characterized by a temporary lapse of consciousness, which typically lasts up to ten seconds, and they are accompanied by spike-wave discharges (SWDs) in cerebral electroencephalogram (EEG) recordings. The oscillatory activity that underlies cortical SWDs has been shown to often originate from a specific focus that can be located in various brain regions, such as the cerebral cortex, thalamus or hippocampus [1]. Yet, the role of the cerebellum, which is anatomically connected to each of these potential foci, is unknown. Here, we used Cacnalatottering $(t g)$ mice, an established model for absence epilepsy characterized by a loss-of-function of

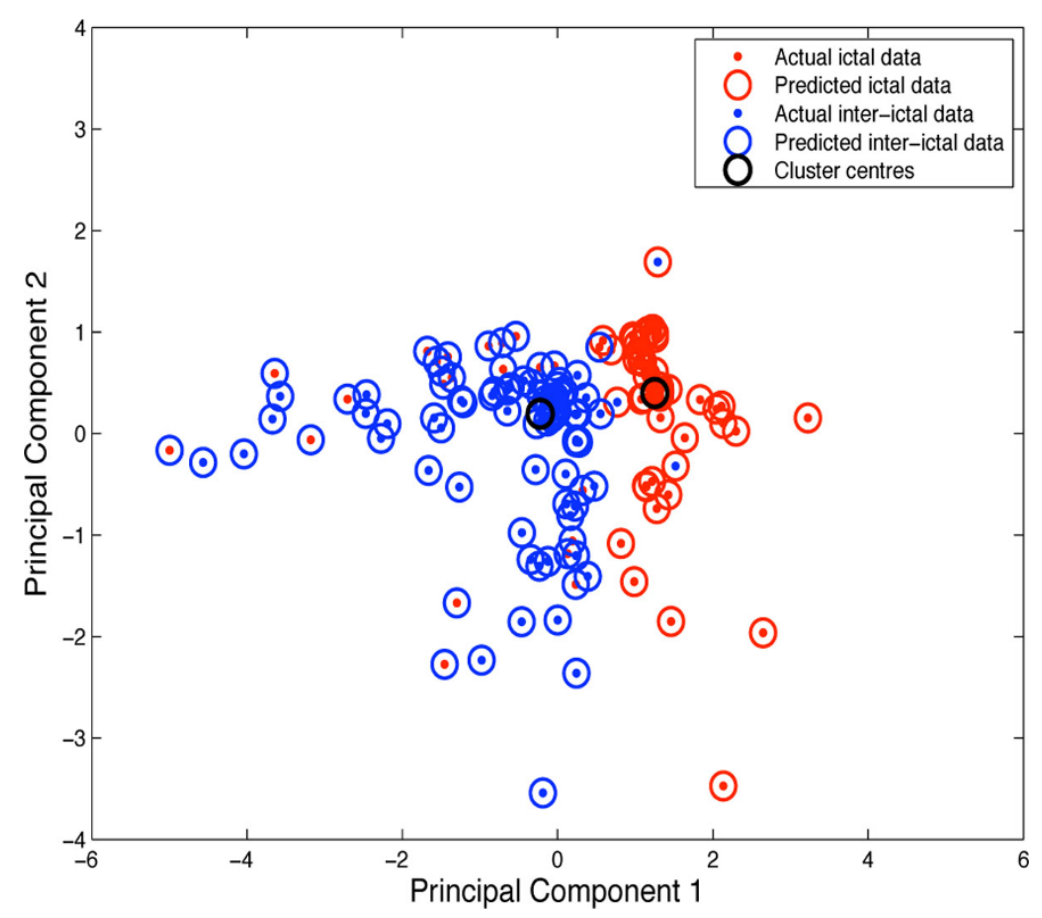

Figure $1 \mathrm{~K}$-Means clustering showing two distinct clusters for ictal and inter-ictal data. The two variables, principal component 1 and principal component 2 are derived by PCA of CV, CV2 and PE of ictal and inter-ictal data.

\footnotetext{
* Correspondence: p.alva2@herts.ac.uk

'Science and Technology Research Institute, University of Hertfordshire, Hatfield, AL10 9AB, UK

Full list of author information is available at the end of the article
}

(c) 2013 Alva et al; licensee BioMed Central Ltd. This is an Open Access article distributed under the terms of the Creative Commons 
calcium channels [3], to study how the cerebellar activity changes during absence seizures. Given that recent evidence shows that cerebellar Purkinje cells in tottering mice exhibit an altered expression of calcium channels [2] and structurally abnormal synapses in the cerebellar nuclei $(\mathrm{CN})$, it is our hypothesis that the cerebellar output, which is dominated by neurons in the $\mathrm{CN}$, changes during absence seizures.

In the present study, we analysed extracellular spike trains of $\mathrm{CN}$ units, and simultaneous EEG recordings, in ten awake head-restrained mice. The recordings were partitioned into equal-length segments of $900 \mathrm{~ms}$ and, depending on whether spike-wave discharges occurred in the EEG or not, considered as ictal or inter-ictal data. The metrics considered for analysis were the $\mathrm{CV}, \mathrm{CV} 2$, firing rate and permutation entropy (PE). When a one-dimensional analysis of the metrics for ictal and inter-ictal data was conducted, it was noted that a single metric was not sufficient to differentiate between the ictal and inter-ictal data. Therefore, the three variables, CV, CV2 and PE, were combined to form two new variables, Principal Component 1 and Principal Component 2 (Figure 1), using Principal Component Analysis (PCA). The two new variables, Principal Component 1 and Principal Component 2, were then subjected to cluster analysis using K-Means clustering having two centers. Firing rate was not considered for PCA and clustering as better results were achieved while excluding it.

The result, shown in Figure 1, depicts two distinct clusters for ictal and inter-ictal data. The confusion matrix for this data denotes true positive where predicted ictal data match actual ictal data (95.7\%), true negative where predicted inter-ictal data match actual inter-ictal data (70\%), false positive for actual ictal data incorrectly predicted as inter-ictal data (4.3\%), and false negatives for actual interictal data incorrectly predicted as ictal data (30\%). The F-score achieved by this classification was 0.84 . The separation between the ictal and inter-ictal data could further be improved by the application of Support Vector Machines (SVMs). We are currently using a conductance based model of a $\mathrm{CN}$ neuron to study which conditions can result in spike patterns associated with seizures.

\footnotetext{
Author details

${ }^{1}$ Science and Technology Research Institute, University of Hertfordshire, Hatfield, AL10 9AB, UK. ²Department of Neuroscience, Erasmus Medical Center, Rotterdam, The Netherlands. ${ }^{3}$ Department of Cognitive Sciences, École Normale Supérieure, Paris 75005, France.

Published: 8 July 2013

References

1. Danober L, Deransart C, Depaulis A, Vergnes M, Marescaux C. Pathophysiological mechanisms of genetic absence epilepsy in the rat. Progress in Neurobiology 1998, 55(127):57.
}

2. Hoebeek FE, Khosrovani S, Witter L, De Zeeuw Cl: Purkinje cell input to cerebellar nuclei in tottering: ultrastructure and physiology. Cerebellum 2008, 7(4):547-558.

3. Noebels JL, Sidman RL: Inherited epilepsy: spike-wave and focal motor seizures in the mutant mouse tottering. Science 1979, 204(4399):1334-1336.

doi:10.1186/1471-2202-14-S1-P170

Cite this article as: Alva et al:: A potential role for the cerebellar nuclei in absence seizures. BMC Neuroscience 2013 14(Suppl 1):P170.
Submit your next manuscript to BioMed Central and take full advantage of:

- Convenient online submission

- Thorough peer review

- No space constraints or color figure charges

- Immediate publication on acceptance

- Inclusion in PubMed, CAS, Scopus and Google Scholar

- Research which is freely available for redistribution

Submit your manuscript at www.biomedcentral.com/submit 